\title{
INTERNATIONAL COVENANT ON CIVIL AND POLITICAL RIGHTS (ICCPR)
}

\section{Introduction}

[1] The 1966 International Covenant on Civil and Political Rights (ICCPR) is one of the most important human rights $\rightarrow$ treaties in the world. Together with its sister Covenant, the $\rightarrow$ International Covenant on Economic, Social and Cultural Rights (ICESCR), it forms the treaty versions of the $1948 \rightarrow$ Universal Declaration of Human Rights (UDHR). As of 14 June 2021, it has global coverage with 173 state parties. It covers a wide range of rights, which are guaranteed for everybody, regardless of race, sex, religion, or other status.

[2] The ICCPR was adopted in 1966 and came into force on 23 March 1976 in accordance with its Article 49, three months after the deposit of the $35^{\text {th }}$ instrument of ratification.

[3] The ICCPR is supplemented by two Optional Protocols. The first Optional Protocol (OP1) was adopted by the UN General Assembly at the same time as the ICCPR itself, in 1966, and provides for an optional $\rightarrow$ individual communications mechanism. It came into force on the same date as the ICCPR. As at 14 June 2021, it has 116 state parties. The Second Optional Protocol (OP2) was adopted in 1989 and prohibits the $\rightarrow$ death penalty. It came into force on 11 July 1991 and has 89 state parties as of 14 June 2021.

\section{Historical Development of the ICCPR}

[4] Soon after the adoption of the UDHR in 1948 ( $\rightarrow$ soft law), work commenced within the $\rightarrow$ United Nations (UN) to turn that Declaration into a binding treaty. However, the work stalled due to political differences during the early Cold War $(\rightarrow$ historical development of international human rights). While the UDHR took three years to finalise, it was to be eighteen further years (until 1966) before the two treaty versions of the UDHR were adopted by the UN.

[5] One of most significant decisions during the drafting of the ICCPR was to separate it from the ICESCR, taken by the UN General Assembly in 1952 (UNGA, Res 543 (VI) [1952]). This decision reflected how Western states perceived differences between the two sets of rights. In particular, Western states viewed civil and political rights as $\rightarrow$ justiciable negative rights, essentially requiring states to refrain from rights abusive actions. In contrast, Western states viewed economic, social and cultural rights as non-justiciable positive goals or aspirations, requiring proactive and often expensive state actions for their fulfilment. Despite opposition from the Eastern bloc, the decision was ultimately made to divide the rights between two treaties (McGoldrick [1994] paras 1.16 and 1.25; $\rightarrow$ generations of human rights).

[6] The perceived differences between the two sets of rights are manifested in the different obligation provisions of the two Covenants. While Article 2(1) of the ICESCR stipulates that the rights therein are to be implemented progressively $(\rightarrow$ core obligations and progressive realization) and are dependent on a state's 'maximum available resources', no such leeway is given to states under Article 2(1) of the ICCPR. That provision requires a state party 'to respect and to ensure to all individuals within its territory and subject to its jurisdiction the rights recognized in the present Covenant' once the treaty enters into force for that state: the obligation is immediate. Moreover, the ICCPR established a monitoring body, the UN Human Rights Committee (HRCttee), while no such body was established for the ICESCR until 1986. Finally, commitment to the justiciability of ICCPR rights was confirmed by the adoption of OP1 in 1966, which provided for an individual complaints mechanism, 42 years before a similar Optional Protocol was adopted for the ICESCR. 
[7] The rights in the ICCPR largely reflect the corresponding rights of the UDHR. Some drafting differences arise, generally because the provisions of the ICCPR are more detailed. Some UDHR rights are missing from both Covenants, such as its Article 13, guaranteeing the right to seek $\rightarrow$ asylum, and Article 17, protecting the right to $\rightarrow$ property. One apparent qualitative change arose regarding the $\rightarrow$ freedom of thought, conscience and religion. Article 18 of the UDHR explicitly refers to the right to 'change' religion, whereas that word is missing from the guarantee of freedom of religion in Article 18 of the ICCPR, largely at the behest of Muslim states. Nevertheless, Article 18 of the ICCPR has been interpreted to guarantee the right to change one's religion anyway (HRCttee, GC No 22: Thought, Conscience or Religion [1993] para 5).

\section{Procedural Aspects}

1. The UN Human Rights Committee

[8] The HRCttee is the international body which supervises and monitors the implementation of the ICCPR. It is established under Article 28 of the ICCPR, and came into being in 1977, soon after the ICCPR came into force. It is a made up of 18 human rights experts who serve in a personal rather than a governmental capacity. Half of the HRCttee is elected by the states parties to the ICCPR every two years to serve four year terms. Candidates are nominated by their state of nationality. The HRCttee membership should reflect a fair geographical split in terms of numbers of members from each of the UN's five geographical regions. There are no term limits for members. The HRCttee meets at the UN human rights headquarters in Geneva for three sessions a year for three weeks at a time, while a smaller group including officeholders (e.g. Chair, Vice-Chair, relevant Rapporteurs) convenes for a week in advance of each main meeting.

[9] The HRCttee is a quasi-judicial body rather than an international court, as is the case for all of the UN treaty bodies. Its decisions are not legally binding under international law, however they are an authoritative interpretation of the ICCPR as a legally binding treaty $(\rightarrow$ sources of international law). Furthermore, the obligation to act in good faith in relation to both ICCPR and Optional Protocol obligations, as required under Article 26 of the Vienna Convention on the Law of Treaties 1980, requires states parties to engage genuinely in HRCttee procedures and to cooperate with it (HRCttee, GC No 33: Obligations under the OP [2009] para 15).

[10] The $\rightarrow$ International Court of Justice (ICJ) dealt with the legal value of General Comments and decisions by the HRCttee in Ahmadou Sadio Diallo ([2010] para 66), when interpreting Art 13 ICCPR. While the ICJ held that it was not bound to the HRCttee's interpretation of the ICCPR, it 'ascribe[d] [them] great weight' in order to ensure 'the necessary clarity and the essential consistency of international law, as well as legal security', both for state parties and individuals (ibid). Of course, interpretations of the ICCPR which are adopted by the ICJ are legally binding in international law upon the parties in a contentious case.

[11] The HRCttee has a number of functions. Its roles concern: $\rightarrow$ state reports, individual communications under OP $1 ; \rightarrow$ inter-state communications; and the adoption of $\rightarrow$ General Comments.

\section{State Reports}

[12] Under Article 40 of the ICCPR, a state party must submit an initial report on the implementation of ICCPR rights within a year of the treaty coming into force, and thereafter as requested by the HRCttee. Periodic reports are called for roughly every five years. The 
HRCttee has very occasionally called for emergency reports during human rights crises, such as reports from certain states of the former Yugoslavia in the early 1990s. Third parties, particularly human rights $\rightarrow$ civil society organizations from the relevant state, also submit relevant information about a state.

[13] The HRCttee examines the state's report in a dialogue with state representatives. It then issues Concluding Observations, listing positive and negative aspects of a state's performance, and difficulties in implementation, along with recommendations for improved compliance. The Concluding Observations serve as a type of ICCPR 'report card' for a state.

[14] A rapporteur within the HRC will publicly follow up the state to seek information on the extent of its compliance with particular recommendations in the interim before the next periodic report is submitted. The cycle recommences upon the submission of the next periodic report.

\section{Individual Communications under the Optional Protocol}

[15] Ratification or accession to OP1 means that a state authorizes the submission by individuals of communications to the HRCttee regarding alleged breaches of their ICCPR rights by that state. Of the 173 parties to the ICCPR, 116 are state parties to the OP1 as at April 2020. The HRCttee finalizes about 20 to 30 communications in each session.

[16] A communication will be registered with the HRCttee unless it fails to satisfy basic criteria: the communication must not be anonymous, it must be in writing, and it must concern a State party to the Optional Protocol. Arguments are almost always presented in writing, though oral hearings have been permitted in exceptional cases since 2016. For example, oral evidence was given in HRCttee, Miller and Carroll v New Zealand [2017]. The case was deemed to have the requisite importance, and it was also felt that oral evidence would help clarify the complexities of the impugned law concerning preventive detention (HRCttee, Guidelines on making oral comments concerning communications [2019]). From 2020, the HRCttee has signalled that it will occasionally invite and accept third party amicus briefs in OP1 cases (HRCttee, Guidelines on Information and Documentation submitted by Third Parties [2020]).

[17] There are two stages to the consideration of a communication: $\rightarrow$ admissibility and merits. In rare cases, where inadmissibility is blatant, a case can be dismissed by the HRCttee without being sent to a state party for information and relevant arguments. There are several admissibility hurdles, which include the following. The communication must concern an actual alleged violation of the rights of an identifiable victim: it cannot be an abstract complaint in the nature of an actio popularis. Under the ratione temporis rule, the communication must relate to a set of circumstances which arose after the date that the OP1 entered into force for the relevant state. The relevant alleged circumstances must arise within the scope of the ICCPR (ratione materiae), and within the scope of the state's jurisdiction (ratione loci). Sufficient evidence must be submitted to substantiate the complaint. Under Article 5(2)(a) of the OP1, the communication must not be simultaneously before 'another procedure of international investigation or settlement', such as an individual communications procedure before another UN human rights treaty body, or a case before a regional human rights court like the $\rightarrow$ European Court of Human Rights. Finally, domestic remedies in respect of the complaint which underlies a communication must be exhausted ( $\rightarrow$ exhaustion of domestic remedies), according to Article 5(2)(b) of the OP1.

[18] There are complex nuances within these rules of admissibility. For example, the ratione temporis rule may be displaced if a violation commences before the date of coming into force of the Optional Protocol, but is affirmed and continues after that date ( $\rightarrow$ state responsibility). Similarly, there are numerous exceptions to the domestic remedies rule. For example, 
domestic remedies do not have to be exhausted if they are futile or ineffective, or where pursuance of such a remedy is likely to expose a person to reprisals.

[19] If a communication is found to be admissible, the HRCttee considers the merits of a communication: did the state violate or not violate an ICCPR right? It normally proceeds directly to the merits once admissibility is established, but sometimes it will seek further arguments from the author of the complaint and the respondent state. It ultimately issues its final Views on the matter. If a violation is found, it will add recommendations for remedial action. A rapporteur within the HRCttee will follow up a state over its progress in complying with the recommendations, and will report on its progress or lack thereof.

\section{Interim Measures}

[20] During consideration of a communication, the HRCttee will sometimes request that a state comply with interim measures ( $\rightarrow$ urgent measures) in order to prevent action from being taken which causes irreparable damage to an alleged victim. For example, interim measures have often been requested in relation to communications concerning the imposition of the death penalty to prevent the carrying out of a death sentence while the HRCttee deliberates (e.g. HRCttee, Thompson $v$ St Vincent and the Grenadines [2000] paras 4.1-4.2). The same arises in communications where the subject of the challenge is a decision to deport a person (e.g. HRCttee, Kwok Yin Fong v Australia [2009] para 1.2).

[21] Disregard for interim measures renders the HRCttee's deliberations in a relevant case 'nugatory and futile' (HRCttee, Piandiong et al v Philippines [2000] para 5.2). For example, in that case a complaint about the imposition of the death penalty was rendered moot when the complainant was executed despite a request for interim measures. The HRCttee takes very seriously instances of such disregard. In General Comment No 33 [2009] it stated:

Failure to implement such interim or provisional measures is incompatible with the obligation to respect in good faith the procedure of individual communication established under the Optional Protocol (para 19).

[22] The HRCttee seems to be suggesting that non-compliance with interim measures in fact breaches international law, in the form of the good faith obligations undertaken upon ratification of the Optional Protocol (Naldi [2004] at 449). Hence, it is possible that requests for interim measures are essentially binding while compliance with the final views are not. In this respect, it may be noted that compliance with interim measures is generally very high, and much higher than compliance with final views.

\section{Inter-State Complaints}

[23] Under Article 41 of the ICCPR, a state party can authorize the submission of inter-state communications against it, that is complaints of alleged ICCPR violations by another state. Article 41 sets out an elaborate process for the consideration of such complaints. By April 2020, no such communication had ever been submitted to the HRCttee, so the process had never been utilized.

\section{General Comments}


[24] As of mid-2021, the HRCttee has issued 37 'general comments' under Article 40(4) of the ICCPR. These are comments adopted by consensus within the HRCttee issued to all state parties which expand upon particular elements of the ICCPR and its OPs. Most General Comments constitute interpretations of particular ICCPR rights. Some General Comments concern other issues, such as the requirements of a state's report, the status of HRCttee decisions under the first Optional Protocol, derogations and reservations. Some General Comments concern issues that cut across a number of rights, such as General Comment No 28 on Equality of Rights between Men and Women (2000). While the earliest General Comments were rudimentary in their reasoning, the General Comments from the 1990s onwards have become increasingly detailed and extensively referenced. General Comments are now valuable jurisprudential resources.

[25] Alongside its General Comments, the HRCttee sometimes issues other documents adopted as consensus statements on specific issues. For example, in early 2020 , it issued a Statement on Derogations from the Covenant in connection with the COVID-19 pandemic. These statements are adopted more quickly than General Comments, and with less consultation (e.g. with states and civil society) over their content. They have some normative value, though are likely to be less influential than the General Comments.

\section{Reservations}

[26] $\rightarrow$ Reservations are permitted to the ICCPR and many reservations have been entered thereto. Under $\rightarrow$ customary international law, as codified in Article 19(c) of the Vienna Convention on the Law of Treaties, reservations to treaties are invalid to the extent that they are incompatible with the object and purpose of the relevant treaty. The HRCttee endorsed this customary rule in General Comment No 24 (1994) and outlined an extensive list of types of reservations which would violate this rule. These include reservations to those ICCPR rights recognized as 'peremptory norms' of international law ( $\rightarrow$ jus cogens). Some states objected to the extensive nature of that list (UNGA, Observations under Article 40, Paragraph 5, of the Covenant: France [1997]; UNGA, Observations on General Comment 24: United States [1996]).

[27] The General Comment specifies certain departures from the ordinary international law rules on reservations with regard to ICCPR reservations. For example, the ICJ has stated that an invalid reservation means that the relevant state is not considered to be a party to the relevant treaty (ICJ, Reservations to the Genocide Convention (Advisory Opinion) [1951] at 29). In the view of the HRCttee, however, a state with an invalid reservation is treated as a party which has not made the relevant reservation. Several states rejected this contention (France, Observations on General Comment 24; United Kingdom, Observations on General Comment 24; United States, Observations on General Comment 24). The International Law Commission (ILC) sets out a presumption that supports the HRCttee's interpretation in its Guide to Practice on Reservations (ILC, Guide to Practice on Reservations to Treaties [2011] Guideline 4.5.3). The presumption is however weak, as the ILC recognizes the option for states to convey an intention to the HRCttee not to be bound by the ICCPR in the absence of the reservation within twelve months of a finding by that body that its reservation is invalid.

\section{Denunciation}

[28] The ICCPR is silent on the issue of denunciation, as is OP2. Only one state, the Democratic People's Republic of Korea (DPRK/'North Korea') in 1997, has ever attempted to denounce, or withdraw from, the ICCPR. The HRCttee issued General Comment No 26 in 
response, where it explained why, in its view, denunciation of the ICCPR was impossible. It stated that ICCPR rights accrue to the people of a state upon ratification: 'such protection devolves with territory and continues to belong to them, notwithstanding changes in Government of the State party [...]' (HRCttee, GC No 26: Continuity of Obligations [1997] para 4). The same reasoning indicates that denunciation is similarly not possible from the OP2.

[29] The DPRK submitted a state report after its denunciation was rejected, indicating that it accepted the HRCttee's arguments. However, it has not reported since the issuance of the Concluding Observations in respect of that report in 2001.

[30] The OP1 explicitly allows denunciation in its Article 12. Several Caribbean states denounced the OP1 in the late 1990s, in order to stop the large number of individual communications concerning the imposition of death sentences. Jamaica has not rejoined while Guyana and Trinidad and Tobago rejoined immediately upon denunciation, but with reservations purporting to prohibit the consideration of individual communications relating to prisoners on death row. In HRCttee, Kennedy $v$ Trinidad and Tobago [2002], a complaint concerning the death penalty, the HRCttee found the state party's reservation to be invalid. Trinidad and Tobago subsequently denounced the OP1 again, and has not rejoined since. Guyana remains a state party after its second accession.

\section{Succession}

[31] Successor states are treated as parties to the ICCPR (HRCttee, GC No 26: Continuity of Obligations [1997] para 4; see also $\rightarrow$ succession into human rights treaties). For example, China is the successor state regarding the city states of Hong Kong and Macau, succeeding to, respectively, the UK in 1997 and Portugal in 1999. This is so even though China itself is not a party to the ICCPR. China has accepted this situation and accordingly submits periodic reports and engages in related dialogues with the HRCttee regarding both territories.

[32] A number of successor states to the USSR have purported to accede to the ICCPR, perhaps indicating a belief that they were not in fact parties simply by virtue of succeeding to a previous state party (Beemelmans [1997] at 89).

[33] It may be noted that South Sudan has not yet reported to the Human Rights Committee, despite being a successor state to Sudan. As of June 2021, it had not yet reported to any treaty body.

\section{Substantive Aspects}

[34] As its name indicates, the ICCPR covers civil and political rights. These rights largely concern rights relating to one's bodily autonomy (e.g. right to $\rightarrow$ freedom of movement, right to freedom from $\rightarrow$ torture, right to freedom from arbitrary detention), spiritual autonomy (e.g. $\rightarrow$ freedom of conscience and religion), fair treatment (e.g. right to $\rightarrow$ fair trial, rights of $\rightarrow$ nondiscrimination) and political rights (e.g. right to vote) (Joseph [2010] at 90). These categories overlap. For example, $\rightarrow$ freedom of opinion and expression can be viewed as a right relating to spiritual autonomy (e.g. speaking one's mind, seeking and receiving information that one wishes to receive), fair treatment (e.g. it enables one to convey the information needed to facilitate due process), and political rights (to convey and receive political information).

[35] In the 18 years of the drafting of the Covenants, many more states joined the original 48 in the UN, as the process of decolonization sped up. The influence of the newly decolonized states is evident in the recognition of the $\rightarrow$ right of self-determination in identical terms in Article 1 of both treaties. Article 1 is distinctive because it is the only explicitly $\rightarrow$ collective right 
in the ICCPR (and the ICESCR): it is a right of $\rightarrow$ peoples rather than a right belonging to individuals. Moreover, it is the only article in Part I of both Covenants.

[36] Part III contains the other substantive rights, which belong to individuals. Part II contains supporting guarantees, such as the overarching obligation provision in Article 2(1), general guarantees of non-discrimination in Articles 2(1) and 3, a derogations provision in Article 4, and a savings provision in Article 5 (meaning that the rights in the ICCPR cannot be interpreted so as to permit the destruction of the ICCPR rights of others; $\rightarrow$ abuse of rights).

[37] Part IV establishes the HRCttee, along with its reporting and inter-state complaints functions. Part $V$ contains further savings provisions, ensuring for example that the ICCPR is not interpreted as 'impairing' the UN Charter. Part VI addresses signature and ratification, and outlines a procedure for amendment of the ICCPR, which has never been utilised.

\section{Positive and Negative Rights}

[38] Even though civil and political rights were assumed to be negative rights during the drafting process, as explained above, there are significant positive aspects to ICCPR rights $(\rightarrow$ negative and positive obligations). For example, the right to a fair trial in Article 14 cannot be properly guaranteed without positive actions such as the establishment of courts and provision of trained impartial judicial officers. Election infrastructure must be provided in order to properly guarantee the right to vote in Article 25(b). Indeed, every right contains positive and negative elements (HRCttee, GC No 31: Nature of Obligations [2004] para 6).

[39] A positive obligation which is embedded in each of the rights relates to the effect of the right in the private sphere. Human rights obligations traditionally bind state actors. However, all rights including ICCPR rights are now recognized as having some regulatory impact on $\rightarrow$ non-state actors. States are required to exercise $\rightarrow$ due diligence to ensure that a person's ICCPR rights are not harmed within jurisdiction by a third party. As an example, the $\rightarrow$ right to life in Article 6 protects against killings by the state, but also, indirectly, killings by third parties. States must take reasonable measures to prevent instances of homicide, such as by enacting and enforcing appropriate laws. They must also investigate instances of apparently culpable homicide and punish perpetrators appropriately (HRCttee, GC No 31: Nature of Obligations [2004] para 8).

\section{Absolute Rights}

[40] Some rights in the ICCPR are absolute; they cannot be interfered with in any circumstance $(\rightarrow$ absolute and relative rights). Article 7 , the right to be free from torture, cruel and inhuman degrading treatment or punishment, is such a right. No circumstance will justify interference with this right by the state. The same is true of Article 8(1) (freedom from $\rightarrow$ slavery) and 8(2) (freedom from servitude).

\section{Limitations to ICCPR Rights}

[41] In contrast, most ICCPR rights are subject to permissible limitations $(\rightarrow$ limitations and restrictions of rights). The permissibility of limitations is expressed in different words in different rights.

[42] Explicit limitation clauses are found in Articles 12 (freedom of movement), 18 (freedom of conscience and religion); 19 (freedom of expression); 21 (freedom of assembly) and 22 (freedom of association). Such clauses have certain requirements for valid rights restrictions. First, limitations must be provided for or prescribed by law. This means that they must be 
circumscribed in an actual law, rather than imposed at the whim of a decision-maker. They must also use proportionate means to achieve a legitimate purpose enumerated in the provision. For example, Article 19(3) specifies that a limit must be 'provided by law' and 'necessary' (that is, proportionate) in order to achieve one of the ends listed in Articles 19(3)(a) or 19(3)(b). The enumerations of legitimate purposes in limitation clauses are similar but not identical: they normally include ends such as the protection of public health, public morals, national security, and the rights of others.

[43] One common legitimate purpose for rights limitations is the protection of public order. In English language versions of the ICCPR, the mention of public order is always accompanied by the French $\rightarrow$ 'ordre public'. Public order is an English common law concept which has no perfect analogue in civil law or in the French language: ordre public is a broader concept (Joseph and Castan [2013] at 18.56). So far, however, the difference between the two concepts has not proven to be problematic in the decisions and interpretations of the HRCttee. No interpretation appears to have fallen in the gap that exists between the narrower concept of public order and the broader concept of ordre public.

[44] Another common legitimate purpose is the protection of the rights and freedoms of others. In General Comment 37 (2020), the HRCttee confirmed, at least in regard to Article 21 (freedom of assembly), that this term refers to 'the protection of Covenant or other human rights'. While it has long been clear that the limitation covers human rights outside the ambit of the ICCPR, this is an overdue acknowledgement that the limitation does not protect rights beyond recognized human rights, such as mere domestic legal rights. This limitation recognizes that human rights can clash, and the state must then balance one right against another on a case by case basis. For example, freedom of expression in Article 19 can clash with the right to reputation in Article 17 in the context of an allegedly defamatory statement.

[45] In certain provisions, permissible limitations of rights are expressed in other ways than through a limitation clause. Articles 6(1) (right to life), 9(1) (freedom from arbitrary detention) and 17(1) (right to privacy) provide that interferences must not be 'arbitrary'. In each of those provisions, the limitation must again be provided for under the law (for example, under Article 17(2)). The word 'arbitrary' again imports the notion of proportionality. Hence, the main difference between the formula of the limitation clause and the use of the word 'arbitrary' is that the permissible purposes or objectives of a limiting law are not explicitly listed in the latter instance. While one might assume that more limitations are allowed in the absence of the enumerated limitation clauses, this is not evident from the interpretations of the HRCttee.

\section{Derogations to ICCPR Rights}

[46] Article 4 of the ICCPR provides for derogations from the rights therein in times of public emergency ( $\rightarrow$ emergency, state of), such as an $\rightarrow$ armed conflict, a $\rightarrow$ natural disaster, or a pandemic. Derogations are only permissible to the extent that they are necessitated by the 'exigencies' of the relevant situation. Hence, derogations must be proportionate.

[47] Certain rights are non-derogable under Article 4(2), such as the right to life (Art 6), the right to be free from torture, cruel and inhuman degrading treatment or punishment (Art 7), the freedoms from slavery and servitude (Art 8(1) and 8(2)), and the freedoms of conscience and religion (Article 18). In General Comment No 29 (2001), the HRCtttee has also considered that some other rights, not listed in Article 4(2), are effectively non-derogable. Such a status arises, according to the HRCttee, either from their peremptory status in international law (e.g. the prohibition of arbitrary detention in Article 9(1) (HRCttee, GC 29: State of Emergency [2001] para 11), or their instrumental role as procedural rights which are essential for protecting the 
explicit non-derogable rights (e.g. Art 9(4) (HRCttee, GC 29: State of Emergency [2001] para 16).

[48] Article 4(3) requires official notification to the UN of the derogation, including the reasons therefore, its nature, and its duration. However, a state's failure to comply with the notification requirements does not deprive it of its substantive rights of derogation under Article 4(1) (e.g. HRCttee, Landinelli Silva et al v Uruguay [1981].

\section{Extraterritoriality}

[49] Article 2(1) of the ICCPR requires that states respect and ensure ICCPR rights to all within their territory and jurisdiction. It has been interpreted as having some $\rightarrow$ extraterritorial application (HRCttee, GC No 31: Nature of Obligations [2004] para 10). In addition to obligations within their territory, states must ensure the enjoyment of ICCPR rights in territories under their effective control. For example, the HRCttee has made inquiries of the US regarding the enjoyment of ICCPR rights in Guantanamo Bay, despite its location within the sovereign territory of Cuba, due to the US's effective control over that territory (HRCttee, Concluding Observations: US [2014]). States also have extraterritorial obligations to a person outside their territory where they have effective control over that person. For example, the HRCttee found that Uruguay violated the ICCPR when its agents kidnapped a political opponent in Argentina and brought him back to Uruguay: Uruguay was responsible for the period of detention in Argentina prior to his being brought over the border (HRCttee, Lopez v Uruguay [1981]), as well as his subsequent detention and treatment in Uruguay. Cases have also related to the extraterritorial refusal of passports in violation of the freedom of movement in Article 12 (HRCttee, Vidal Martins v Uruguay [1982]). Extraterritorial obligations under the ICCPR were ostensibly extended in A.S. and others $v$ Malta [2021] and A.S. and others $v$ Italy [2021]. In both cases, the 13 victims, who were amongst over 200 who drowned in the Mediterranean Sea after a migrant boat sank, were held to come within the jurisdiction of two states parties, Malta and Italy respectively, who had failed to rescue them. The case against Malta, in whose territorial waters the migrant vessel had sank, was dismissed due to a failure to exhaust domestic remedies. However, Italy was found by a majority to have violated rights to life due to the proximity of an Italian navy ship to the sinking vessel, and its failure to respond promptly to distress calls and requests for assistance from Maltese authorities which might have saved lives. In both cases, the respondent state had a more remote jurisdictional link to the victims than in earlier cases such as Lopez (Milanovic (2021)).

\section{Significant Interpretations}

[50] The HRCttee's jurisprudence under OP1 has been dominated by certain issues and complaints against certain countries. There was a preponderance of cases in the 1980s regarding allegations of murder, torture, detention and $\rightarrow$ enforced disappearance by the military government of Uruguay. In the 1990s, complaints against Caribbean nations regarding allegedly unfair capital trials proliferated. Since the turn of the century, there have been numerous disappearance cases against Libya and Algeria. Hence, there is a disproportionate number of cases concerning the rights to life (Art 6), freedoms from torture and ill treatment (Art 7) and arbitrary detention (Article 9) and ill treatment in detention (Art 10), and fair trial rights (Art 14). Nonetheless, there are significant cases touching upon all ICCPR rights.

[51] For example, the HRCttee has issued important decisions on human rights breaches entailed in strict anti-abortion laws (HRCttee, Mellet $v$ Ireland [2016]), on the absolute right of conscientious objection to $\rightarrow$ military service (HRCttee, Jeong et al $v$ Republic of Korea [2011]), 
and on the rights of some non-nationals to be free from deportation and remain in their country of residence (HRCttee, Nystrom v Australia [2011]). It has taken a liberal approach to European laws which forbid Islamic clothing $(\rightarrow$ religious clothing) which covers the face, such as the burqa (HRCttee, Yaker v France [2018]): it has found violations of the right to freedom of religion in such cases in circumstances where the European Court of Human Rights has not (ECtHR, S.A.S. v France (GC) [2014]). In late 2019, it considered whether New Zealand's deportation of a person to his home state of Kiribati was a breach of the right to life, given the vulnerability of that state to rising sea levels and $\rightarrow$ climate change. While no violation was found, the decision signals that 'climate refugees' may soon have rights to be free from expulsion to their states of origin under the ICCPR (HRCttee, Teitiota v New Zealand [2019]).

[52] One of the HRCttee's most ground-breaking decisions remains Broeks $v$ Netherlands, decided in 1990. The case concerned the scope of the non-discrimination provision in Article 26 (HRCttee, Broeks v Netherlands [1990]). Broeks concerned a complaint by an unemployed married woman about her lack of entitlement to unemployment benefit in a circumstance where a married man would have been so entitled. The Netherlands argued that the communication concerned the $\rightarrow$ right to social security, a right found in Article 9 of the ICESCR but not the ICCPR, and was thus inadmissible. The HRCttee found that the case in fact concerned nondiscrimination on the basis of sex, hence confirming that Article 26 protected against discrimination with regard to the enjoyment of any right, whether civil, political, economic, social or cultural. At the time, the decision was very controversial, as it extended the scope of the ICCPR, including its enforcement machinery, well into the realm of ICESCR rights. The Broeks interpretation is now well entrenched, having prevailed after three decades.

\section{Practical Relevance}

[53] The HRCttee's effectiveness is undercut by significant lack of compliance by ICCPR state parties. With many states, there is procedural non-compliance in the form of late (including extremely late) reports (Pillay [2012] at 9), or a failure to respond to calls for information regarding a communication under the Optional Protocol. The HRCttee has responded to such recalcitrance. For example, it will on occasion examine a state's ICCPR record in the absence of a report. A state's failure to provide information in respect of an individual communication will mean that a petitioner's allegations are unchallenged, which increases the likelihood of a finding of violation.

[54] Substantive non-compliance also arises. A review of the HRCttee's follow-up materials indicates that less than half of its Optional Protocol Views are complied with, and a similar observation may be made about recommendations from Concluding Observations. For example, Australia is a country with a long democratic history and commitment to the $\rightarrow$ rule of law. Yet Australia has a poor record of implementing both Committee Views and Concluding Observations (Joseph, Fletcher and Lochhead-Sperling [2021]). In this regard, the HRCttee is hampered by its quasi-judicial status. It seems that its effectiveness is therefore less than that of regional courts such as the European Court of Human Rights.

[55] The HRCttee must ensure that its interpretations are of high quality in order to promote greater compliance. For example, some of its decisions contain sparse reasoning, which reduces their credibility (Joseph and Castan [2013] at 1.143). Furthermore, the HRCttee suffers from a lack of funding from UN members. Indeed, overall funding for the treaty body system has not adequately increased to take account of an increase in treaty bodies.

[56] Some significant reforms have taken place in order to streamline the HRCttee's procedures. For example, it now sends lists of issues to states to facilitate more focused 
reports and dialogues. It has also streamlined consideration of the admissibility and merits stages of an OP1 communication. While reforms may increase procedural compliance, a greater increase in procedural and substantive compliance depends mainly on the political will of states, and consistent high quality outputs from the HRCttee.

[57] HRCttee jurisprudence still has an impact even where a state fails to comply. The relevant interpretation has universal relevance, and thus may influence decisions in other states. Furthermore, the impact of the HRCttee may be distinguished from the impact of the treaty itself. The ICCPR has been directly incorporated into the law of many states, such as the Netherlands, Finland, Russia, and the Republic of Korea (South Korea). It also provides the template for numerous domestic laws, such as the charters of rights in Hong Kong and in three Australian jurisdictions: the Australian Capital Territory, Victoria and Queensland. Its norms are also utilized in the absence of incorporation, as they can nevertheless influence court decisions, such as the seminal Mabo case in developing Australian common law concerning Indigenous land rights (High Court of Australia, Mabo v Queensland [1992]). Indeed, its norms influence the actions of governments, courts, lawyers, human rights institutions and civil society across the world (Joseph and Castan [2013] at 1.145). Hence, there are numerous avenues for the $\rightarrow$ domestic implementation and enforcement of the ICCPR. Unfortunately, domestic incorporation does not guarantee high quality domestic interpretation and implementation of the ICCPR. Nevertheless, domestic implementation is generally preferable to vindication before the HRCttee: domestic remedies are almost always more accessible, efficient and effective compared to international remedies.

\section{Conclusion}

[58] The ICCPR is a key source of global human rights norms, recognizing a wide range of rights and applying to the people of most states in the world. A rich jurisprudence under the ICCPR has developed over its nearly half a century of operation from the HRCttee, and also from domestic courts. Despite positive reforms over the years, improvements can still be made to the HRCttee, and to the human rights treaty monitoring system in general, as recognised by the UN General Assembly in 2014 (UNGA, Res 68/268 [2014]). That matter was considered by the UN General Assembly in 2020 (UNGA, Res 75/174 [2020]), but with no concrete outcomes beyond recommendations for more follow-up reports in 2023. The largest improvement needs however to come from state parties themselves, in terms of the political will to consistently and conscientiously adhere to the ICCPR's obligations.

SARAH JOSEPH

\section{Bibliography}

International Covenant on Civil and Political Rights (adopted 16 December 1966, entered into force 23 March 1976) 999 UNTS 171 (ICCPR) - Optional Protocol to the International Covenant on Civil and Political Rights (adopted 16 December 1966, entered into force 23 March 1976) 999 UNTS 171.

Beemelmans $\mathrm{H}$, 'State Succession in International Law: Some Remarks on Recent Theory and State Praxis' (1997) 15 Boston University International Law Journal $71 \bullet$ Joseph S, 'Civil and Political Rights' in Baderin M and Ssenyonjo M (eds), International Human Rights Law: Six Decades after the UDHR and Beyond (Ashgate 2010) 89 • Joseph S and Castan M, The International Covenant on Civil and Political Rights: Cases, Materials and Commentary (OUP 2013) • Joseph S, Fletcher A and Lochhead-Sperling A, 'Australia' in Heyns C, Viljoen F and 
Murray R (eds), Study on the Impact of the United Nations Human Rights Treaties on Domestic Law (Brill, forthcoming, 2021) • McGoldrick D, The Human Rights Committee: The Role in the Development of the International Covenant on Civil and Political Rights (OUP 1994) • Milanovic, M, 'Drowning Migrants, the Human Rights Committee, and Extraterritorial Human Rights Obligations' (2021) EJIL: Talk!, 16 March 2021 • Naldi G, 'Interim Measures in the UN Human Rights Committee' (2004) 53 The International and Comparative Law Quarterly 445 • Schabas W, Nowak's CCPR Commentary: UN International Covenant on Civil and Political Rights (N.P. Engel, $3^{\text {rd }}$ ed, 2019).

Case law, International: S.A.S. v France (GC) App no 43835/11 (ECtHR, 1 July 2014) • A.S. et al $v$ Italy, HRCttee (28 April 2021) UN doc CCPR/C/128/D/3042/3017 • A.S. et al v Malta (28 April 2021) UN doc CCPR/C/128/D/3043/3017 • Broeks $v$ the Netherlands, HRCttee (9 April 1987) UN Doc CCPR/C/29/D/172/1984 • Jeong et al $v$ Korea, HRCttee (27 April 2011) UN Doc CCPR/C/101/D/1642-1741/2007 • Kennedy v Trinidad and Tobago, HRCttee (26 March 2002) UN Doc CCPR/C/74/D/845/1998 • Kwok Yin Fong v Australia, HRCttee (23 November 2009) UN Doc CCPR/C/97/D/1442/2005 • Landinelli Silva et al $v$ Uruguay, HRCttee (8 April 1981) UN Doc CCPR/C/12/D/34/1978 • Lopez v Uruguay, HRCttee (29 July 1981) UN Doc CCPR/C/13/D/52/1979 • Mellet v Ireland, HRCttee (17 November 2016) UN Doc CCPR/C/116/D/2324/2013 • Miller and Carroll v New Zealand, HRCttee (19 November 2018) UN Doc CCPR/C/119/D/2502/2014 • Nystrom v Australia, HRCttee (1 September 2011) UN Doc CCPR/C/102/D/1557/2007 • Piandiong et al $v$ the Philippines, HRCttee (20 December 2000) UN Doc CCPR/C/70/D/869/1999 • Teitiota v New Zealand, HRCttee (7 January 2020) UN Doc CCPR/C/127/D/2728/2016 • Thompson v St. Vincent and the Grenadines, HRCttee (18 October 2000) UN Doc CCPR/C/70/D/806/1998 • Vidal Martins v Uruguay, HRCttee (23 March 1982) UN Doc CCPR/C/15/D/57/1979 • Yaker v France, HRCttee (7 December 2018) UN Doc CCPR/C/123/D/2747/2016 • Reservations to the Convention on the Prevention and Punishment of the Crime of Genocide (Advisory Opinion) [1951] ICJ Rep $15 \bullet$ Ahmadou Sadio Diallo (Republic of Guinea v Democratic Republic of the Congo) (Merits) [2010] ICJ Rep 639 - Domestic: Mabo v Queensland (High Court, Australia) 3 June 1992, 175 CLR 1.

UN Documents: HRComm 'The Siracusa Principles on the Limitation and Derogation Provisions in the International Covenant on Civil and Political Rights' (28 September 1984) UN Doc E/CN.4/1985/4 • HRCttee 'Concluding Observations on the Fourth Periodic Report of the United States of America' (23 April 2014) UN Doc CCPR/C/USA/CO/4 • HRCttee 'General Comment 22: Freedom of Thought, Conscience and Religion' (27 September 1993) UN Doc CCPR/C/21/Rev.1/Add.4 • HRCttee 'General Comment 24: Issues Relating to Reservations Made upon Ratification or Accession to the Covenant or the Optional Protocols thereto, or in Relation to Declarations under Article 41 of the Covenant' (4 November 1994) UN Doc CCPR/C/21/Rev.1/Add.6 • HRCttee 'General Comment 26: Continuity of Obligations' (8 December 1997) UN Doc CCPR/C/21/Rev.1/Add.8/Rev.1 • HRCttee 'General Comment 28: The Equality of Rights Between Men and Woman' (29 March 2000) UN Doc CCPR/C/21/Rev.1/Add.10 • HRCttee 'General Comment 29: States of Emergency' (31 August 2001) UN Doc CCPR/C/21/Rev.1/Add.11 • HRCttee 'General Comment 31: The Nature of the Legal Obligation Imposed on States Parties to the Covenant' (26 May 2004) UN Doc CCPR/C/21/Rev.1/Add.13 • HRCttee 'General Comment 33: Obligations of States Parties under the Optional Protocol to the International Covenant on Civil and Political Rights' (5 November 2008) UN Doc CCPR/C/GC/33 • HRCttee 'General Comment 37: Right of Peaceful Assembly' (27 July 2020) UN Doc CCPR/C/GC/37 • HRCttee 'Guidelines on Making Oral 
Comments Concerning Communications' (26 March 2019) UN Doc CCPR/C/159/Rev. 1 • HRCttee, Guidelines on Information and Documentation submitted by Third Parties (3 September 2020) UN doc CCPR/C/160 - HRCttee 'Statement on Derogations From the Covenant in Connection with the COVID-19 Pandemic' (30 April 2020) UN Doc CCPR/C/128/2 - ILC 'Guide to Practice on Reservations to Treaties' (2011) UN Doc A/66/10 para $75 \bullet$ UNGA 'Observations of States Parties under Article 40, Paragraph 5, of the Covenant: France, Observations Transmitted by Letter Dated 8 September 1995' (13 April 1997) UN Doc A/51/40, Annex VI • UNGA 'Observations on General Comment No. 24 (52), on Issues Relating to Reservations Made Upon Ratification or Accession to the Covenant or the Optional Protocols thereto, or in Relation to Declarations under Article 31 of the Covenant: United Kingdom of Great Britain and Northern Ireland, Observations Transmitted by Letter Dated 21 July 1995' (4 February 1996) UN Doc A/50/40 • UNGA 'Observations on General Comment No. 24 (52), on Issues Relating to Reservations Made Upon Ratification or Accession to the Covenant or the Optional Protocols thereto, or in Relation to Declarations under Article 31 of the Covenant: United States of America, Observations Transmitted by Letter Dated 28 March 1995' (4 February 1996) UN Doc A/50/40, Annex VI • UNGA Res 543 (VI) (5 February 1952) 'Preparation of Two Draft Covenants on Human Rights' UN Doc A/RES/543(VI) • UNGA Res 68/268 (21 April 2014) 'Strengthening and Enhancing the Effective Functioning of the Human Rights Treaty Body System' UN Doc A/RES/68/268 • UNGA Res 75/174 (16 December 2020) 'Human Rights Treaty Body System'.

Documents, Others: Centre for Civil and Political Rights <https://www.ccprcentre.org> accessed 1 June 2021 - Human Rights Committee <https://www.ohchr.org/en/hrbodies/ccpr/pages/ccprindex.aspx> accessed 1 June $2021 \bullet$ Pillay N, 'Strengthening the United Nations human rights treaty body system: A Report by the United Nations High Commissioner for Human Rights' (OHCHR 2012). 